\title{
Lactobacillus casei (Orla-Jensen) comb. nov.
}

\author{
P. A. HANSEN and ERWIN F. LESSEL \\ University of Maryland, College Park, Maryland, \\ and the American Type Culture Collection, \\ Rockville, Maryland 20852
}

\begin{abstract}
The name Lactobacillus casei, although applied for half a century to a well-described, well-known, clearly defined bacterium, has not been validly published, hence it has no standing in nomenclature. However, according to the rules of the International Code of Nomenclature of Bacteria (1966), there are no impediments to $L$. casei being proposed as a new combination. Therefore, recognizing the principle of stability in nomenclature, the authors propose Lactobacillus casei (Orla-Jensen) comb. nov. as the name of the organism described by von Freudenreich $(1889-1890 ; 1891)$ under the designation Bacillus $\alpha$ and later named Streptobacterium casei by Orla-Jensen (1919). ATCC 393 (Streptobacterium casei No. 7 of OrlaJensen) is designated as the neotype strain of Lactobacillus casei.
\end{abstract}

The name Lactobacillus casei has been used for 50 years for the bacterium with the following salient characteristics:

Short or long, straight rods occurring in chains, the length of which depends upon the medium; in milk the chains are usually much shorter than they are in broth.

Gram-positive.

Nonmotile.

Endospores not produced.

Lactic acid (mainly L $[+]$ ), with only trace amounts of by-products, produced from carbohydrates. In milk, about $1.5 \%$ lactic acid is produced.

Growth in milk slow, curdling usually occurring in 3 to 5 days at $30 \mathrm{C}$, but sometimes much more slowly.

Casein utilized under certain conditions.

Temperature range of growth: 10 to $40 \mathrm{C}$, some strains up to but not over $45 \mathrm{C}$.

Riboflavine required.

Pentoses are rarely attacked. Glucose, fructose, mannose, galactose, lactose, cellobiose, and trehalose are fermented. Maltose and sucrose are usually attacked, but the fermentation may be slow. Melibiose is never fermented. Raffinose, inulin, and starch are not fermented.

Despite the fact that this species is welldescribed and established, a careful search and analysis of the literature has revealed that according to the rules of the International Code of Nomenclature of Bacteria the name Lactobacillus casei has never been validly published. Because this name is accepted and used throughout the world for a clearly defined species of bacterium for which viable cultures of a reference strain are available, it is only common sense to retain the name, within the framework of the Bacteriological Code.

The purposes of this paper are to review the nomenclature of the species under consideration, to establish Lactobacillus casei as its validly published and legitimate name, and to designate the neotype strain of this organism.

\section{DISCUSSION}

The following is an annotated list of the various names and designations which have been applied to the species referred to above; the rules cited are those of the International Code of Nomenclature of Bacteria (4):

1. Bacillus $\alpha$ and "Bacillus $\alpha$ du fromage." Used by von Freidenreich $(11,12)$, the first to describe this organism. According to Rules $14 \mathrm{a}(1)$ and $25 \mathrm{~b}$, Bacillus $\alpha$ was not validly published because $\alpha$ does not constitute a legitimate specific epithet.

2. Bacillus casei $\alpha$. Von Freudenreich and Thöni (13, p. 532) used this designation in place of Bacillus $\alpha$, and it is not validly published by reason of Rule $14 \mathrm{a}(1)$ and $25 \mathrm{~b}$.

3. Caseobacterium vulgare. Orla-Jensen $(8$, p. 35) mentions this name but gives no indication that he is introducing it as a new name, therefore it is not validly published (Rule $12 \mathrm{c}$ [3]). The fact that Orla-Jensen did not accept this name, i.e., did not use it or the specific 
epithet vulgare for the same organism in his subsequent publications on this organism, also renders it not validly published (Rule 12c [1]).

4. Bacterium casei $\alpha$. Listed as a synonym of Caseobacterium vulgare by Orla-Jensen (8, p. 35), hençe not validly published (Rule 12d); also not validly published for the same reason cited in 1 above.

5. Streptobacterium casei. Although this name was validly published by Orla-Jensen ( 9 , p. 166), it is an illegitimate combination because the generic name Streptobacterium OrlaJensen 1919 (9) is illegitimate as a later homonym of Streptobacterium Jacqué and Masay 1912 (5). However, the specific epithet case i is itself legitimate and available for use in combination with an available generic name, providing there are no obstructions to its use in the new combination. $S$. casei Orla-Jensen is the basionym of the name of the organism here under discussion.

6. Lactobacillus casei. Holland (3, p. 223), the first to use this combination, did not clearly indicate that it was being proposed as a new name or combination; as a consequence, $L$. casei was not validly published by Holland (Rule 12c). Furthermore, Holland neither described the organism nor gave a reference to a previous description, and on this account $L$. casei as mentioned by Holland does not meet the requirements for valid publication (Rule 12a). The only reference that Holland gives to Orla-Jensen is his 1909 paper, in which there is no mention of Bacterium casei $\alpha$, cited by Holland as a synonym of $L$. casei.

Bergey et al. (1, p. 253), who used "Lactobacillus casei (von Freudenreich)," are frequently cited as the authors of the name Lactobacillus casei when applied to the organism which is the subject of this paper. However, Bergey et al. gave no indication whatsoever that they were proposing $L$. casei as a new name or combination, and the name is therefore not validly published by Bergey et al. (Rule 12c [3] and accompanying Note). (As proof that Bergey et al. did not intend to introduce Lactobacillus case $i$ as a new combination in the first edition of their Manual, Holland is cited as the author of $L$. casei in all subsequent editions of Bergey's Manual, four of which were edited by Bergey et al.)

From a careful examination of the literature, then, it is apparent that the name Lactobacillus casei has not, at the time of this writing, been validly published and thus has no standing in nomenclature (Rule 12a, Note). Because the name $L$. case $i$ has never been validly published,
TABLE 1. Descriptions of ATCC 393 (the neotype strain of Lactobacillus casei) and of Bacillus $\alpha$ of von Freudenreich

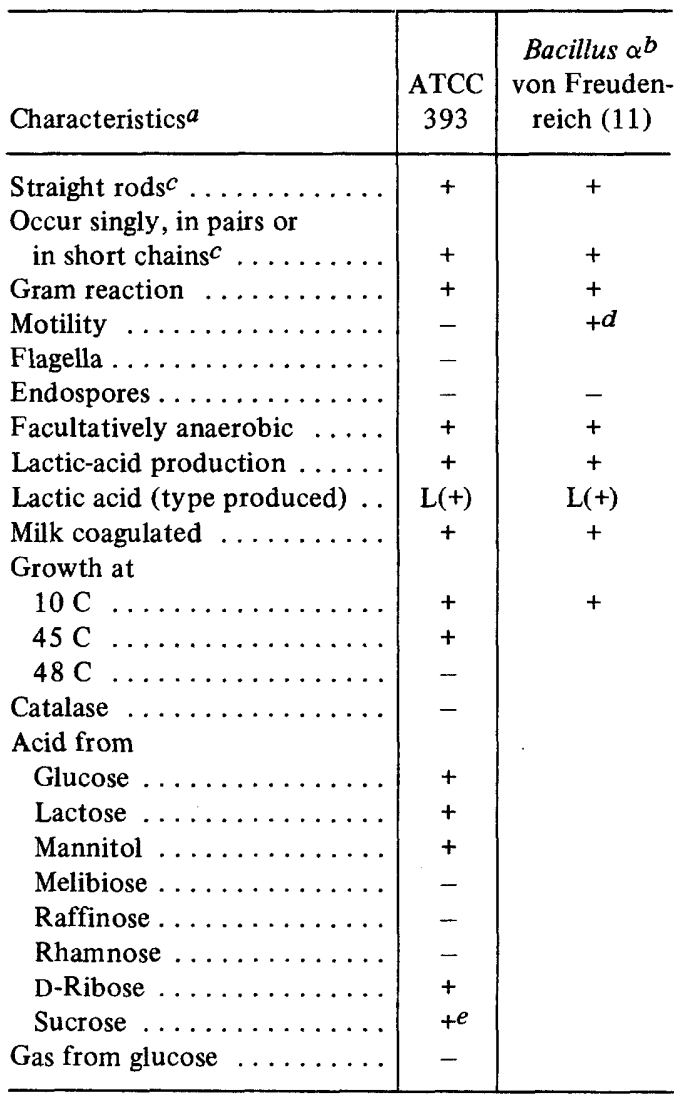

$a$ See Hansen (2) and von Freudenreich (11) for methods.

$b$ Although a few additional characters of Bacillus $\alpha$, such as colonial morphology and resistance to heat and chemical agents, were given by von Freudenreich (11), only those which are currently regarded as taxonomically significant are cited here.

$c$ The length of both cells and chains is influenced by the growth medium: in liquid media the cells are shorter and the chains longer than those produced on solid media; furthermore, the chains formed in milk are usually much shorter than those in broth. Von Freudenreich (11) described the rods from solid media as being short (ca. $1 \mu \mathrm{m}$ ) with rounded ends.

$d$ Von Freudenreich (11) records a very slow motility that is difficult to detect. Motility was clearly noticeable when individual cells separated from the chains. This type of motility does not appear to be the same as that ordinarily exhibited by flagellated bacteria.

$e$ In Orla-Jensen's (9) original description of this strain, the fermentation of sucrose is given as lacking or very weak. The variation in sucrose fermentation depending on the medium used is discussed by Orla-Jensen $(9,10)$. 
it is available for proposal as a new combination.

7. Lactobacterium casei. Krasil'nikov (6, p. 215) mentions this name, but it also must be regarded as not validly published because Krasil'nikov did not state or indicate that he was proposing a new name or combination (Rule 12c [3]).

ATCC 393 (Orla-Jensen's strain no. 7 of Streptobacterium casei) was designated by Hansen (2, p. 59 and 76-77) as the type strain of the species under discussion. However, there is no evidence that this strain is one of the strains on which the author who first described this organism (i.e., von Freudenreich [11]) based his description, and it is therefore not eligible for designation as the type. Furthermore, it appears that none of von Freudenreich's original strains are extant. Consequently ATCC 393, a strain which has the characters recorded in the original description of this organism by von Freudenreich [11] (see Table 1) and which agrees in its characters with the current concept of this species, is here designated as the neotype strain for Lactobacillus casei.

\section{CONCLUSIONS}

A thorough scrutiny of the scientific literature has revealed that the commonly used name Lactobacillus casei has never been proposed in conformity with the rules of the International Code of Nomenclature of Bacteria, and, consequently, has not been validly published. Recognizing that this name has been in use for 50 years for what is presently a well-described and easily recognized bacterium, the authors propose Lactobacillus casei (Orla-Jensen 1919) comb. nov. (basionym: Streptobacterium casei Orla-Jensen 1919) as the name of this organism.
ATCC 393 is designated as the neotype strain of Lactobacillus casei.

\section{LITERATURE CITED}

1. Bergey, D. H., F. C. Harrison, R. S. Breed, B. W. Hammer, and F. M. Huntoon. 1923. Bergey's manual of determinative bacteriology, 1 st ed. The Williams \& Wilkins Co., Baltimore.

2. Hansen, P. A. 1968. Type strains of Lactobacillus species. American Type Culture Collection, Rockville, Md.

3. Holland, D. F. 1920. Generic index of the commoner forms of bacteria. J. Bacteriol. 5:215-229

4. International Code of Nomenclature of Bacteria 1966. Int. J. Syst. Bacteriol. 16:459-490.

5. Jacqué, L., and F. Masay. 1912. Le Streptobacterium foetidum, agent pathogène nouveau de l'homme. Zentralbl. Bakteriol. I Abt. Orig. 62:180-186.

6. Krasil'nikov, N. A. 1949. Guide to the bacteria and actinomycetes. Akad. Nauk, U.S.S.R., Moscow.

7. Orla-Jensen, S. 1909. Die Hauptlinien des natürlichen Bakteriensystems. Zentralbl. Bakteriol. II Abt. 22:305-346.

8. Orla-Jensen, S. 1916. Maelkeri-Bakteriologi. Sch $\varnothing$ nbergske Forlag, K $\varnothing$ benhavn.

9. Orla-Jensen, S. 1919. The lactic acid bacteria. E. Munksgaard, København.

10. Orla-Jensen, S. 1943. The lactic acid bacteria (Die Echten Milchsäurebakterien). Mém. Acad. Roy. Sci. Danemark, Sect. Sci. Biol. 2(3):1-145.

11. von Freudenreich, E. 1889-1890. Recherches prèliminaires sur le role des bactéries dans la maturation du fromage de 1'Emmenthal. Ann. Microgr. 2:257-283.

12. von Freudenreich, E. 1891. Bakteriologische Untersuchungen über den Reifungsprozess des Emmenthalerkäses. Landw. Jb. Schweiz 5:16-29.

13. von Freudenreich, E., and I. Thöni. 1904. Über die Wirkung verschiedener Milchsäurefermente auf die Käsereifung. Landw. Jahrb. Schweiz 18:531-554. 